\title{
Octocoral distributions at Carrie Bow Cay, Belize
}

\author{
Howard R. Lasker ${ }^{1}$ and Mary Alice Coffroth ${ }^{2 *}$
}

\author{
${ }^{1}$ Department of Biological Sciences, State University of New York at Buffalo, Buffalo, New York 14260, USA \\ ${ }^{2}$ Rosenstiel School of Marine and Atmospheric Science, 4600 Rickenbacker Cswy, Miami, Florida 33149, USA
}

\begin{abstract}
Abundance and size distributions of octocorals in 4 habitats at Carrie Bow Cay, Belize, were determined from a series of transects taken in April 1982. The 4 habitats studied were a sand-flat, patch reef, forereef and forereef ridge. Octocorals were abundant in all 4 habitats but were most abundant on the forereef. The majority of species were represented by greater numbers of large colonies than by recent recruits (colonies $<10 \mathrm{~cm}$ tall). However, species which had the largest number of small colonies numerically dominated the community. On the sand-flat and forereef, species of the genus Pseudopterogorgia predominated. The great abundance of Pseudopterogorgia spp. was achieved through high rates of recruitment and/or juvenile survival. Briareum asbestinum was the most abundant octocoral on the patch reef and forereef ridge. B. asbestinum uses a second life history strategy in which it relies on vegetative reproduction to produce large numbers of recruits, many of which survive and become large colonies. The plexaurids may exhibit a third life history strategy in which low recruitment in concert with high survival leads to an accumulation of large colonies. These life history patterns are very similar to those previously observed among stony corals.
\end{abstract}

\section{INTRODUCTION}

Octocorals are common and conspicuous members of almost all coral reefs. Despite their commonness, relatively little is known of the distribution and ecology of most octocorals including that of gorgonians, the most abundant octocorals in the Caribbean. The rareness of ecological studies of Caribbean gorgonians may be attributable to the difficulty of identifying specimens in the field. In many cases, identifications can only be made from prepared samples of sclerites, and even then identification is difficult as a result of variability in the appearance of sclerites within species and even within colonies (Bayer, 1961). These difficulties have apparently exempted gorgonians from the intense study which much of the Caribbean reef fauna has undergone over the past 30 үr. Community studies of Caribbean reefs which have concentrated on the gorgonians are restricted to the works of Goldberg (1973) and Opresko (1973) for Florida, and that of Kinzie $(1970,1973,1974)$ for Jamaica. These authors have presented surveys of Caribbean gorgonian faunas and have noted in their respective areas a number of 'communities' which are somewhat specific to different habitats. In addition to their work, a number of authors

- Present address: Dept of Biological Sciences, S. U. N. Y. at Buffalo, Buffalo, New York 14260, USA have studied the plexaurid gorgonian Plexaura homomalla because of its potential for commercial use (Bayer and Weinheimer, 1974). However, with only a few exceptions, quantitative data on the ecological processes regulating octocoral populations are unavailable.

In this study, data are presented on the distribution and abundance of octocorals, primarily gorgonians, on the reefs around Carrie Bow Cay, Belize. The reef system at Carrie Bow Cay has been investigated in some detail by a number of workers (Rützler and Macintyre, 1982), and Muzik (1982) has presented a species list and some distributional data for octocorals at Carrie Bow Cay. However, quantitative data on the abundance and distribution of gorgonians at Carrie Bow Cay have been lacking just as they are for most other Caribbean reef systems. Similarly, there have been few attempts to relate the existing distribution patterns to ecological processes.

\section{METHODS}

The distribution of octocorals at Carrie Bow Cay was determined from a series of transects which were taken in April 1982. Data were collected from three areas which had been previously identified as having abundant gorgonian populations (Muzik, 1982; Rützler and 
Macintyre, 1982). These areas were a backreef patch reef, the lower spur and groove region of the forereef (henceforth referred to as the forereef) and the forereef ridge. The patch reef habitat was further divided into two habitats, patch reef and sand-flat. Locations of the study areas are depicted in Fig. 1.

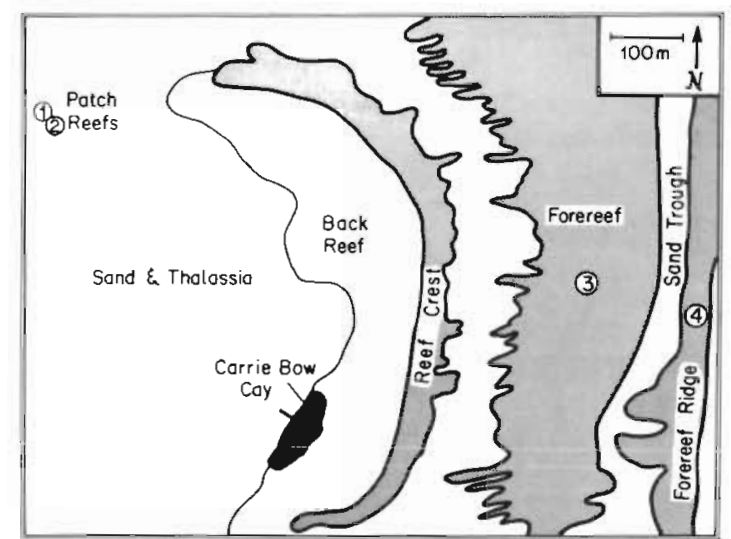

Fig. 1. Carrie Bow Cay and surrounding waters. Study sites: 1 , sand-flat; 2 , patch reef; 3 , forereef; 4 , forereef ridge

The patch reef habitat was located on a coral and rubble slope between 3 and $5 \mathrm{~m}$ depth. Gorgonians were commonly attached to dead surfaces of coral heads. The patch reef was subjected to strong tidal currents, but many of the gorgonians on the slope were somewhat protected from the current. Although the sand-flat was a shallow extension of the patch reef, it was extremely different from the patch reef. The sandflat was a broad plain 2 to $3 \mathrm{~m}$ in depth predominantly composed of rippled sands with occasional pieces of coral rubble. The sand ripples were generated by strong tidal currents which were regularly observed at this site.

Forereef transects were taken at a depth of $10 \mathrm{~m}$. This was a region with a broad shallow slope best described as a hardground regularly interrupted by shallow sand channels. Gorgonians within this habitat were subject to a slight surge.

The forereef ridge runs parallel to the forereef at Carrie Bow Cay. It rises from a shoreward trough at 25 to $30 \mathrm{~m}$ depth to a depth of $18 \mathrm{~m}$. Transects were taken on the top of the ridge perpendicularly across it. Octocorals were common on the ridge except in the occasional sand channels which ran across the ridge. The substrate consisted of overgrown Acropora cervicornis rubble, Madracis sp. and heads of Montastrea annularis. A slight current which ran parallel to the ridge was encountered during all visits to this habitat.

Within each of the areas, a line was set and a series of parallel $10 \mathrm{~m}$ transects was laid out on alternate sides of the line at $5 \mathrm{~m}$ intervals. The number of tran- sects examined within an area was based on the size of the area and the density of gorgonians within the area. For instance, only 3 transects were taken in the patch reef, since only 3 transects could be fit within the patch reef's limits. On the sand-flat and patch reef habitats all colonies within $1.5 \mathrm{~m}$ of the transect line were identified and their height recorded. In many cases, identifications could not be made in the field and specimens were collected for later laboratory identification. All identifications were made using the species descriptions of Bayer (1961). Similar data were collected from the transects on the forereef and forereef ridge, but in these habitats only colonies within $0.5 \mathrm{~m}$ of the transect line were identified. The smaller distance was used because of the high density of gorgonians encountered on these transects.

Size-frequency distributions of the species were used to study the age structure of the populations at each of the sites. Colony size has been used as an estimator of age in several species (Opresko, 1974; Grigg, 1977). Unfortunately, most species were represented by only a few colonies, which precluded the use of detailed size frequency data. Instead, colonies were partitioned into 3 categories. The first two categories 0 to 5 and 5 to $10 \mathrm{~cm}$ included young, recently recruited colonies. Among Plexaura homomalla colonies, $10 \mathrm{~cm}$ tall colonies are probably less than $4 \mathrm{yr}$ old (based on extrapolations of growth rates from Hinman et al., 1974), and Opresko (1974) reports the mean size of $1 \mathrm{yr}$ old colonies as $9 \mathrm{~cm}$. The third category, greater than $1 / 4$ of the species maximum height (at Carrie Bow Cay), was used in order to identify 'older' colonies. Among species whose maximum observed colony height was $40 \mathrm{~cm}$ or less, the colonies were divided into 0 to 5,5 to 10 , and 10 to $40 \mathrm{~cm}$ classes. Maximum height was used in an attempt to normalize for different growth rates, since growth rates of different species probably vary. Admittedly this standardization does not consider the species' different longevities. The $1 / 4$ maximum height standard is an arbitrary standard which removes colonies of intermediate height (and age?) from the analysis, and was chosen in order to make a clear distinction between those population in which recruits were predominant and those in which older colonies were predominant. The procedure is biased toward finding populations numerically dominated by recent recruits, since colonies of intermediate height were excluded from the analysis.

\section{RESULTS}

A total of 1226 octocoral colonies were found in the transects. Of those, 197 were collected for laboratory identification. Thirty-seven species representing 10 
different genera were identified, including 4 Eunicea morphotypes of uncertain affinity. Abundances of each of the species at each area are presented in Table 1. The most common species and their relative abundances as well as several indices of diversity for each of the areas are presented in Table 2.

\section{Sand-flat}

Gorgonians were the most abundant reef epizoan on the sand-flat, but they were restricted to the small pieces of hard substrate. Small colonies of Pseudopterogorgia americana, the most abundant species, were present on almost all available substrates in the area. P. americana colonies made up $58 \%$ of the indi- viduals present and despite the scarcity of substrate the density of $P$. americana was comparable to that of the most abundant species in the other three areas (Table 2). The majority of the P. americana were small, presumably young, colonies. $P$. americana grows to over $1.5 \mathrm{~m}$ in height in some habitats, but over $70 \%$ of the colonies on the sand-flat were less than $20 \mathrm{~cm}$ in height (Fig. 2).

Briareum asbestinum was the next most abundant species, but was restricted to a single transect where it was found on a number of large coral heads. B. asbestinum was entirely absent from the sand and rubble substrate which typified the other 4 sand-flat transects. Pseudopterogorgia blanquillensis and Pterogorgia citrina, though not as common as $P$. americana were both characteristic of the area and were absent from the other three habitats.

Table 1. Abundances of octocoral species in 4 habitats at Carrie Bow Cay, Belize

\begin{tabular}{|c|c|c|c|c|}
\hline \multicolumn{5}{|c|}{ Abundance (colonies $\mathrm{m}^{-2}$ ) } \\
\hline Species & Sand-flat & Patch reef & Forereef & Forereef ridge \\
\hline Briareum asbestinum & 0.19 & 4.60 & 0.04 & 4.44 \\
\hline Eunicea calyculata & & & 0.32 & 0.10 \\
\hline E. c. forma coronata & & & & 0.06 \\
\hline E. fusca & & & & 0.02 \\
\hline E. laxispica & & & 0.16 & 0.08 \\
\hline E. palmeri & 0.01 & & 0.04 & \\
\hline E. succinea & & & & 0.04 \\
\hline E. s. forma plantaginea & 0.03 & & 0.08 & \\
\hline E. tourneforti & & & 0.24 & \\
\hline E. t. forma atra & & & 0.24 & \\
\hline Eunicea 1 & 0.01 & & & \\
\hline Eunicea 2 & & & 0.04 & 0.02 \\
\hline Eunicea 3 & & & 0.16 & 0.04 \\
\hline Eunicea 4 & & & & 0.02 \\
\hline Eunicea spp. & 0.09 & 0.13 & 0.24 & 0.22 \\
\hline Gorgonia ventalina & 16.13 & 0.17 & 1.80 & 0.28 \\
\hline G. mariae & & & 0.56 & 0.04 \\
\hline Muricea muricata & 0.03 & & 0.04 & 0.02 \\
\hline Muriceopsis flavida & 0.04 & 0.07 & 0.32 & 0.90 \\
\hline Plexaura flexuosa & 0.07 & 0.03 & 0.36 & 0.12 \\
\hline P. homomalla & 0.13 & 0.07 & 0.24 & 0.14 \\
\hline P. h. kukenthali & & & 0.32 & 0.50 \\
\hline Plexaurella dichotoma & 0.01 & 0.03 & 0.16 & \\
\hline P. grisea & 0.05 & & & \\
\hline$P$. spp. & 20.01 & 0.03 & & \\
\hline Pseudoplexaura flagellosa & 0.05 & 0.10 & 0.28 & \\
\hline P. porosa & 0.08 & 0.20 & 0.36 & 0.02 \\
\hline Pseudoterogorgia acerosa & 0.12 & & 2.08 & 0.06 \\
\hline$P$. americana & 1.87 & & 3.32 & 0.22 \\
\hline P. bipinnata & & & 0.16 & \\
\hline P. blanquillensis & 0.15 & & & \\
\hline$P$. elisabethae & 0.53 & & 0.16 & \\
\hline P. kallos & 0.01 & 0.07 & 5.68 & 0.06 \\
\hline Pterogorgia anceps & 0.04 & & 0.04 & \\
\hline P. citrina & 0.15 & & & \\
\hline P. guadalupensis & 0.13 & & & \\
\hline
\end{tabular}


Table 2. Species abundance and diversity parameters of octocoral communities in 4 habitats at Carrie Bow Cay. The 5 most abundant species as well as their percent abundance are listed for each habitat

\begin{tabular}{|c|c|c|c|c|c|c|}
\hline Habitat & Most abundant species & $\%$ Abundance & \# SP. & $\mathrm{H}^{1}$ & $\mathrm{~J}^{2}$ & Density $^{3}$ \\
\hline Sand-flat: & $\begin{array}{l}\text { P. americana } \\
\text { B. asbestinum } \\
\text { P. blanquillensis } \\
\text { P. citrina } \\
\text { G. ventalina }\end{array}$ & $\begin{array}{l}58.3 \% \\
5.9 \\
4.7 \\
4.7 \\
4.0\end{array}$ & 22 & 2.62 & 0.59 & 3.21 \\
\hline Patch reef: & $\begin{array}{l}\text { B. asbestinum } \\
\text { P. porosa } \\
\text { G. ventalina } \\
\text { Eunicea spp. } \\
\text { P. flagellosa }\end{array}$ & $\begin{array}{r}83.9 \\
3.6 \\
3.1 \\
2.4 \\
1.8\end{array}$ & 12 & 1.18 & 0.33 & 5.48 \\
\hline Forereef: & $\begin{array}{l}\text { P. kallos } \\
\text { P. americana } \\
\text { P. acerosa } \\
\text { G. ventalina } \\
\text { G. mariae }\end{array}$ & $\begin{array}{r}32.4 \\
18.7 \\
11.9 \\
10.0 \\
3.2\end{array}$ & 28 & 3.32 & 0.69 & 17.52 \\
\hline Forereef ridge: & $\begin{array}{l}\text { B. asbestinum } \\
\text { M. flavida } \\
\text { P. homomalla kukenthali } \\
\text { G. ventalina } \\
\text { Eunicea spp. } \\
\text { P. americana }\end{array}$ & $\begin{array}{r}60.3 \\
12.2 \\
6.8 \\
3.8 \\
3.0 \\
3.0\end{array}$ & 22 & 2.44 & 0.55 & 7.36 \\
\hline \multicolumn{7}{|c|}{$\begin{array}{l}1 \text { Pielou (1969) } \\
2 \mathrm{~J}=\mathrm{H}^{\prime} / \mathrm{H}_{\max }^{\prime} \text { Pielou (1969) } \\
3 \text { Density }=\text { colonies } \mathrm{m}^{-2}\end{array}$} \\
\hline
\end{tabular}

\section{Patch reef}

Although it was contiguous with the sandflat, the patch reef's octocoral fauna was strikingly different from that of the sand-flat. The patch reef contained fewer species which were less equitably distributed than the sand-flat fauna (see $\mathrm{J}$ in Table 2). Briareum asbestinum was the most abundant octocoral in the

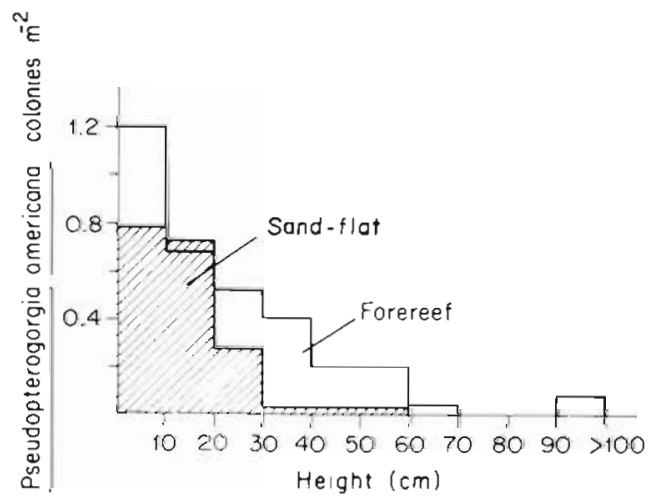

Fig. 2. Pseudopterogorgia americana. Size frequency distribution at sand-flat and forereef habitats community making up $83.9 \%$ of the colonies. Briareum asbestinum colonies were present in almost every square meter of the transects. Pseudoplexaura porosa, P. flagellosa and Plexaura homomalla, though few in number, formed large arborescent colonies which dominated the visual appearance of the reef.

\section{Forereef}

Much of the forereef was densely covered with gorgonians. Colonies could be found on all substrates with the exception of the sand channels and gorgonians were denser in this habitat $\left(17.5\right.$ colonies $\left.\mathrm{m}^{2}\right)$ than in the other 3 areas. The fauna was dominated by species of the genus Pseudopterogorgia, which made up $66 \%$ of the colonies. Gorgonia ventalina, a common constituent of all 4 habitats, reached its greatest density on the forereef. Plexaurids, especially Eunicea, were less common than Pseudopterogorgia, but were more abundant on the forereef than in the other habitats. Briareum asbestinum, a common member of the other habitats, was represented by only a single colony in the 5 forereef transects. 


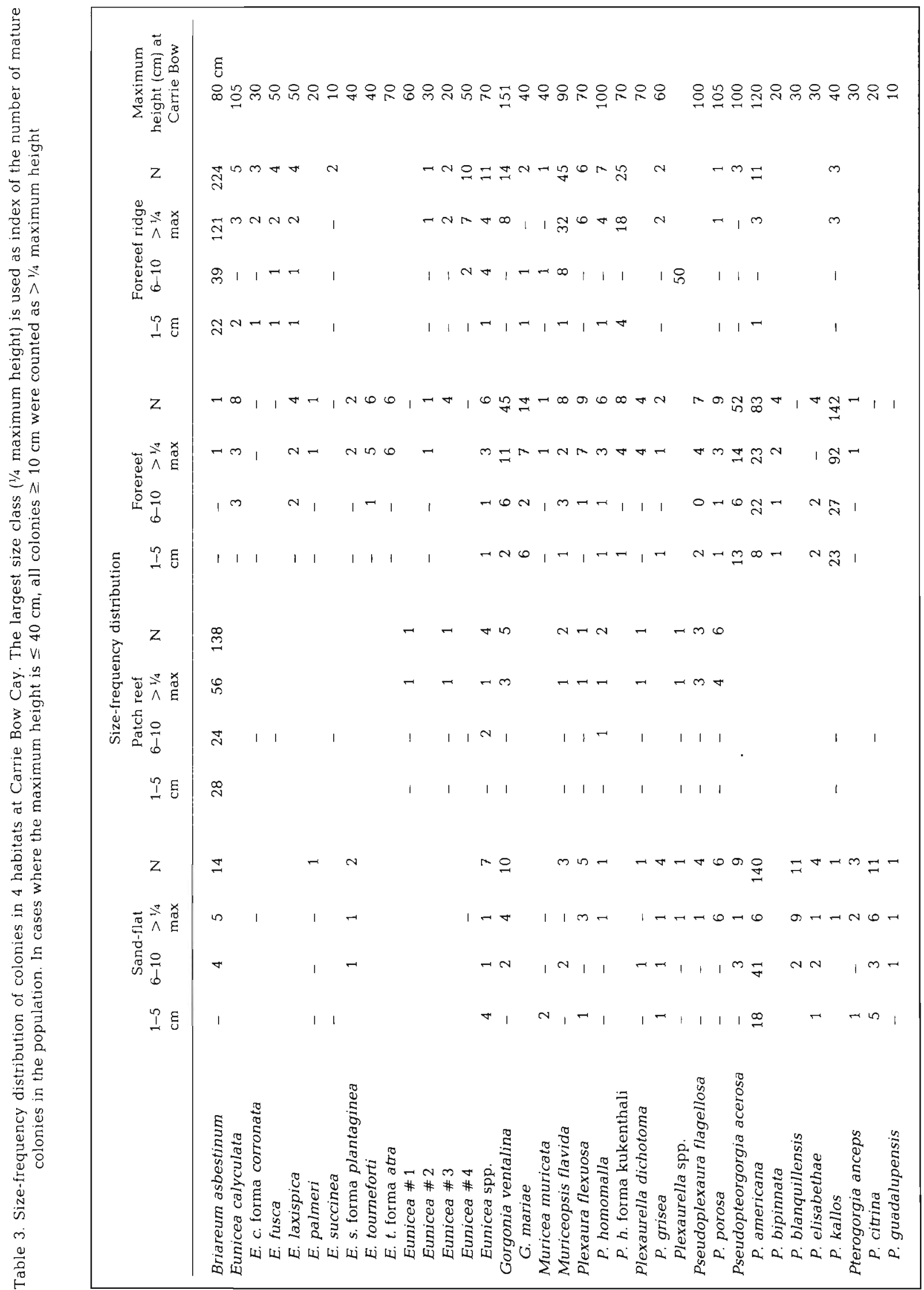




\section{Forereef ridge}

Briareum asbestinum was the most abundant octocoral on the forereef ridge making up $60 \%$ of the total fauna. B. asbestinum was common in areas with a thick layer of loosely packed coral rubble, whereas the other species were usually associated with Montastrea annularis heads which were dispersed throughout the area. Muriceopsis flavida was the most common of these species, but a large number of plexaurids were also found in this habitat.

\section{Size-frequency distribution}

Among most species and in most habitats large colonies were more abundant than those less than $10 \mathrm{~cm}$ in height (Table 3). This trend occurred despite the bias built into the size-frequency analysis. The trend, however, did not apply to all 4 habitats equally. On the sand-flat, large colonies were most common among $59 \%$ of the species, whereas large colonies were most common among 83,75 and $77 \%$ of the species on the patch reef, forereef and forereef ridge, respectively. Small colonies were disproportionately more cornmon on the sand-flat than in the other habitats, and this trend consistently occurred among all species present on the sand-flat.

\section{DISCUSSION}

The factors which control octocoral abundances on Caribbean reefs have been discussed by several authors (Bayer, 1961; Goldberg, 1973; Kinzie, 1973; Opresko, 1973), but few quantitative data are available. For instance, Birkeland (1974), Kinzie (1970) and more recently Wahle (manuscript and in Woodley et al., 1981) are the only authors to quantify mortality processes among Caribbean gorgonians. Most commonly workers have noted the presence of somewhat distinct communities in different habitats and have qualitatively correlated these with environmental factors. The data from Carrie Bow Cay once again reveal the presence of distinct communities.

The octocoral faunas at Carrie Bow Cay overlapped broadly in species composition, but when abundance is also considered the 4 habitats were quite distinct. This pattern is apparent in Table 4 which presents data on the percentage of species in common between habitats and the similarity between species abundances at the different habitats. The 2 habitats most similar on the basis of species composition, the patch reef and sand-flat, are very different when species abundance is taken into account. In like fashion, the
Table 4. Similarities of octocoral faunas in 4 habitats at Carrie Bow Cay, Belize. Two indices of similarity are presented for each comparison (\% of species in common / Pearson correlation coefficient)

\begin{tabular}{lccc|}
\hline & Sand-flat & Patch reef & Forereef \\
\hline & - & & \\
Patch reef & $55 / 0.22$ & - & \\
Forereef & $50 / 0.41$ & $37 / 0.05$ & - \\
Forereef ridge & $33 / 0.07$ & $33 / 0.97$ & $57 /-0.04$ \\
\hline
\end{tabular}

patch reef and forereef ridge have the most sirnilar faunas using the correlation coefficient as the index of similarity, but when species composition is considered the 2 have the most dissimilar faunas.

The similarities and dissimilarities in the octocoral communities at Carrie Bow Cay can be related in part to environmental factors. The data also suggest that octocoral life-history characteristics are important in establishing distinct communities.

Sand-flat. The abundance of Pseudopterogorgia americana and paucity of other species on the sand-flat was most likely a consequence of substrate availability and of the instability of substrates for holdfast attachment. The most common substrates for gorgonians on the sand-flat were the small pieces of unconsolidated coral rubble scattered on the sediment surface. Octocorals growing on these substrates increased drag forces on the rubble which frequently led to overturning of the substrate and/or transport of the colony across the sandflat. Toppling of colonies by strong current action is a well described phenomena (Kinzie, 1970; Birkeland, 1974). The transport of whole colonies with their substrates is less common, but has also been reported. Tunnicliffe (pers, comm.) has observed the transport of gorgonians and their attached substrates on the sills of fjords in British Columbia. Transport and toppling due to currents is dependent on the drag forces on the colony, which are proportional to colony size. On the sand-flat at Carrie Bow, this process has led to increased mortality (or removal) of large colonies. This pattern is evident in Fig. 2 which compares $P$. americana size-frequency distributions from sand-flat and forereef. Small colonies are present in both areas, but large colonies are conspicuously absent on the sand-flat. The 2 distributions are significantly different $\left(\mathrm{X}^{2}=23.99, \mathrm{p}<0.02, \mathrm{df}=11\right)$. The rareness of large colonies on the sand-flat is not restricted to $P$. americana alone. As noted previously, small colonies outnumber large colonies among more species on the sand-flat than in any of the other habitats.

In other habitats, the continued survival of large colonies leads to the accumulation of large colonies within the population. On the sand-flat, however, un- 
stable substrates preclude that longevity and the accumulation of colonies. Therefore, on the sand-flat, those species producing the greatest number of small colonies and presumably the greatest number of recruits are most abundant.

Briareum asbestinum, another species which had a large number of small colonies, was common on one of the sand-flat transects but absent from the other four. $B$. asbestinum relied extensively on the vegetative growth of runners for propagating new colonies. This form of reproduction was not successful in habitats with small isolated substrates surrounded by sand (Lasker, manuscript). The lack of suitable substrate for vegetative propagation prevented $B$. asbestinum from realizing the high recruitment rates observed in other habitats. Plexaurella grisea and Pterogorgia citrina, though present on the sand-flat, were less abundant than in the shallow water habitats described by Opresko (1973). The rareness of these species may also be related to unstable substrates which prevented the accumulation of larger, older colonies.

Patch reef. The patch reef community surveyed at Carrie Bow Cay was the most depauperate of the 4 communities studied. Despite the presence of many healthy large colonies there were fewer species, 12 , and fewer very small colonies than in the other habitats. Excluding Briareum asbestinum, only a single colony $<10 \mathrm{~cm}$ in height was found on the transects. There were many small $B$. asbestinum colonies which was probably a consequence of the availability of substrates for runner growth. As many as $50.7 \%$ of the $B$. asbestinum colonies developed from runners (Lasker, unpubl.). The other species on the patch reef were represented entirely by larger colonies which presumably had accumulated over time as a consequence of low recruitment rates and high survival.

Forereef. The forereef was characterized by clear water, regular water movement, abundant substrates and a dense gorgonian fauna. Pseudopterogorgia kallos, $P$. americana and $P$. acerosa were the dominant species in this habitat and all 3 species had large numbers of very small colonies. The abundance of the 3 Pseudopterogorgia spp. in this habitat is not, however, the arithmetic consequence of the large number of small colonies. These Pseudopterogorgia spp. are the most numerous species in each of the 3 size classes. In addition to these species, a less common group of plexaurids was also present. These species were represented primarily by large colonies and colonies less than $10 \mathrm{~cm}$ in height were rare. As on the patch reef they are believed to have accumulated as a result of their relatively high survivorship rates.

Forereef ridge. Like the preceding habitats, the most abundant species on the forereef ridge was the species with the largest number of small colonies, in this case, Briareum asbestinum. When only larger colonies are considered, B. asbestinum made up $54 \%$ of the total octocoral fauna. As on the patch reef, the abundance of $B$. asbestinum was related to its vegetative reproduction. Up to $80.6 \%$ of the colonies on the forereef ridge developed vegetatively from runners (Lasker, unpubl.). If vegetatively propagated colonies are excluded from the analysis, B. asbestinum loses its position as most abundant species to Muriceopsis flavida.

Some of the octocoral distribution patterns at Carrie Bow Cay can be readily attributed to environmental parameters affecting recruitment or survival. However, much of the pattern cannot be explained. For instance, Pseudopterogorgia americana, P. acerosa and P. kallos all had many successful recruits on the forereef but only $P$. americana had successful recruits on the sandflat. Another interesting replacement occurred going from the forereef to the forereef ridge. Pseudopterogia spp. were abundant on the forereef but absent on the ridge. Muriceopsis flavida, a morphologically similar species, followed the opposite trend. These trends may relate to factors such as light availability, resistance to breaking and substrate specificity, but the causes of the distribution pattern are unknown at this time.

The life history patterns of these species also affect their abundance and the data from Carrie Bow Cay indicate that a number of different reproductive strategies are employed by octocorals. In all 4 habitats the most common species were those which were represented by many small colonies. These species were numerically dominant not only in overall abundance, but in each of the 3 size classes as well. Thus their numerical abundance was not an artifact of a very large number of small colonies, and indicates that a large number of recruits and their subsequent survival were responsible for the species commonness. Of these species, those of the genus Pseudopterogorgia were predominant on the sand-flat and the forereef slope, whereas Briareum asbestinum was predominant on the patch reef and forereef ridge. $B$. asbestinum had high rates of recruitment through vegetative reproduction and also differed from the Pseudopterogorgia spp. in that the number of large colonies was always greater than the number of small colonies. This is not surprising since vegetative reproduction in $B$. asbestinum is dependent on the presence of large colonies which produce runners (Lasker, unpubl.). Therefore, for $B$. asbestinum high densities of large colonies are essential to high recruitment rates. Among purely sexual species there is no necessary correlation between adult density and recruitment since larvae may immigrate from distant populations.

Most of the less abundant species had disproportion- 
ately fewer small colonies than large colonies, and their abundance is best explained by the slow accumulation in the habitat of rare recruits which have high rates of survival. The only area where these species did not occur in any number was on the sand-flat where unstable substrates effectively prevented large colonies from surviving. An alternative to this steady state model states that temporally variable recruitment is responsible for the current paucity of juveniles among the plexaurids. Only long term recruitment data can differentiate between these 2 hypotheses.

These life history strategies exhibit interesting similarities and dissimilarities to those of stony corals. Bak and Engel (1979) described 3 life history patterns in scleractinians: (1) abundant juvenile recruitment, (2) abundant vegetative reproduction, and (3) low rates of recruitment and high survival. Among scleractinians, species with low rates of recruitment are often dominant. Montastrea annularis, one of the most common corals on many Caribbean reefs, has low rates of recruitment at both Curacao (Bak and Engel, 1979) and Jamaica (Rylaarsdam, 1981). Among octocorals at Carrie Bow, however, species with low recruitment rates (as evidenced by the absence of small colonies) were never the most abundant members of the community. In contrast, species with large numbers of small colonies were always the predominant species. This pattern. may indicate a basic difference between the 'ecologies' of scleractinians and octocorals. However, in this study abundance was measured as the number of colonies per square meter, whereas studies of scleractinians frequently record abundance in terms of percent living cover. If biomass (or some other size indicator) was used, perhaps the plexaurids which have few recruits but which produce very large colonies would predominate in some communities.

Acknowledgements. We thank Klaus Rutzler and the Smithsonian Institution Coral Reef Project for making available the facilities at Carrie Bow Cay. Randy Baker and the visiting scientists at Carrie Bow all helped in making our stay on the island productive and enjoyable. We also thank 3 anonymous reviewers for their thoughtful critiques of an earlier draft. This work was partially funded by a Research Development Grant from the State University of New York at Buffalo.

\section{LITERATURE CITED}

Bak, R. P. M., Engel, M. S. (1979). Distribution, abundance and survival of juvenile hermatypic corals (Scleractinia) and the importance of life history strategies in the parent coral community. Mar. Biol. 54: 341-352

Bayer, F. M. (1961). The shallow-water octocorallia of the West Indian region. Martinus Nijhoff, The Hague

Bayer, F. M., Weinheimer, A. J. (ed.) (1974). Prostaglandins from Plexaura homomalla: ecology, utilization and conservation of a major medical marine resource. Stud. Trop. Oceanogr. 12

Birkeland, C. (1974). The effect of wave action on the population dynamics of Gorgonia ventalina Linnaeus. Stud. Trop. Oceanogr. 12: 115-126

Goldberg, W. (1973). The ecology of the coral-octocoral communities off the southeast Florida coast: geomorphology, species composition and zonation. Bull. mar. Sci. 23: $465-488$

Griff, R. W. (1977). Population dynamics of two gorgonian corals. Ecology 58: 278-290

Hinman, J. W., Anderson, S. R., Simon, M. (1974). Studies on experimental harvesting and regrowth of Plexaura homomalla in Grand Cayman waters. Stud. Trop. Oceanogr. 12: 39-57

Kinzie, R. A. III (1970). The ecology of the gorgonians (Cnidaria, Octocorallia) of Discovery Bay, Jamaica. Ph. D. Thesis, Yale University

Kinzie, R. A. III (1973). The zonation of West Indian Gorgonians. Bull. mar. Sci. 23: 93-155

Kinzie, R. A. III (1974). Plexaura homomalla: the biology and ecology of a harvestable resource. Stud. Trop. Biol. 12: $22-38$

Muzik, K. (1982). Octocorallia (Cnidaria) from Carrie Bow Cay, Belize. In: Rützler, K., MacIntyre, I. G. (ed.) The Atlantic barrier reef ecosystem at Carrie Bow Cay, Belize. I. Structure and communities. Smithsonian Inst. Press, Washington, D. C., p. 309-316

Opresko, D. M. (1973). Abundance and distribution of shallow water gorgonians in the area of Miami, Florida. Bull. mar. Sci. 23: 535-557

Opresko, D. M. (1974). Recolonization and regrowth of a population of the gorgonian Plexaura homomalla. Stud. Trop. Oceanogr. 12: 101-110

Pielou, E. C. (1969). An introduction to mathematical ecology. Wiley-Interscience, New York

Rützler, K., Maclntyre, I. G. (ed.) (1982). The Atlantic barrier reef ecosystem at Carrie Bow Cay, Belize, I. Structure and communities. Smithsonian Inst. Press, Washington, D. C.

Rylaarsdamm, K. W. (1981). Life histories and abundance patterns of some Caribbean reef corals. Ph. D. thesis, Johns Hopkins University

Woodley, J. D., Chornesky, E. A., Clifford, P. A., Jackson, J. B. C., Kaufman, L. S., Knowlton, N., Lang, J. C., Pearson, M. P., Porter, J. W., Rooney, M. C., Rylaarsdam, K. W., Tunnicliffe, V. J., Wahle, C. M., Wulff, J. L., Curtis, A. S. G., Dallmeyer, M. D., Jupp, B. P., Koehl, M. A. R., Neigel, J., Sides, E. M. (1981). Hurricane Allen's impact on Jamaican coral reefs. Science, N. Y. 214: 749-754 